\title{
Interactive effects of temperature and phosphorus nutrition on soybean: leaf photosynthesis, chlorophyll fluorescence, and nutrient efficiency
}

\author{
S.K. SINGH ${ }^{*, * *+}$, V.R. REDDY*, D.H. FLEISHER ${ }^{*}$, and D.J. TIMLIN* \\ Adaptive Cropping Systems Laboratory, USDA-ARS, Beltsville, MD, USA* \\ School of Environmental and Forest Sciences, University of Washington, WA, USA ${ }^{* *}$
}

\begin{abstract}
An experiment was conducted to assess interactive effects of temperature $\left(22,26,30\right.$, and $34^{\circ} \mathrm{C}$ daily mean $\left.\mathrm{T}\right)$ and phosphorus (P) fertilization (sufficient, $0.5 \mathrm{mM}$, and deficient, $0.08 \mathrm{mM} \mathrm{P}$ ) on soybean physiological traits. The P deficiency decreased leaf $\mathrm{P}$ concentration over approximately $50 \%$ across temperature regimes. However, a marked decrease in physiological traits under $\mathrm{P}$ deficiency was primarily observed below and at optimum temperature $\left(26^{\circ} \mathrm{C}\right)$ but not at warmer temperatures. This resulted in a significant $\mathrm{P} \times \mathrm{T}$ interaction for parameters such as net photosynthetic rate $\left(P_{\mathrm{N}}\right)$, stomatal conductance, quantum yield of PSII ( $\left.\Phi_{\mathrm{PSII}}\right)$, and SPAD value. A combination of photo-biochemical parameters (e.g., $\Phi_{\mathrm{PSII}}$, carboxylation capacity, SPAD value), improved $\mathrm{CO}_{2}$ diffusion processes due to unaffected or reduced mesophyll or stomatal limitation, and higher tissue $\mathrm{P}$ utilization efficiency appeared to overcome limitations to $P_{\mathrm{N}}$ imposed by $\mathrm{P}$ deficiency at warmer temperatures.
\end{abstract}

Additional key words: chlorophyll fluorescence; compensation; coregulation; nutrient utilization efficiency; optimum temperature.

\section{Introduction}

Soybean [Glycine $\max (\mathrm{L}$.$) Merr.] is an important row crop$ grown worldwide as a source of protein and vegetable oil (Hartman et al. 2011). Plant stresses such as nonoptimal (below and above the optimum) temperatures and $\mathrm{P}$ deficiency adversely affects photosynthetic processes, growth, and productivity of crops including soybean (Cure et al. 1988, Israel and Rufty 1988, Koti et al. 2007, Ruiz-Vera et al. 2013, Xu et al. 2016). High temperature reduces soybean net photosynthesis but increases stomatal conductance $\left(g_{\mathrm{s}}\right)$ and transpiration, whereas P deficiency reduces both the net photosynthesis and $g_{\mathrm{s}}$ (Ruiz-Vera et al. 2013, Singh and Reddy 2016, Xu et al. 2016). In addition, both the stress situations strongly affect chlorophyll fluorescence $(\mathrm{CF})$ processes of the PSII reaction center of the chloroplast and cellular membrane integrity (Koti et al. 2007, Singh and Reddy 2015, Xu et al. 2016). Previous studies in soybean have shown that a temperature above the optimum often leads to the restricted diffusion of $\mathrm{CO}_{2}$ inside the leaves by increasing the stomatal and mesophyll limitations to the photosynthesis (Bernacchi et al. 2002, $\mathrm{Xu}$ et al. 2016). However, an increased stomatal or mesophyll limitation to photosynthesis was not observed in the P-deficient soybean despite a decrease in stomatal and mesophyll conductance (Singh and Reddy 2016).
Studies evaluating crop response to $\mathrm{P}$ fertilization below and above the optimum temperature are extremely limited and to our knowledge, unavailable in soybean (Suriyagoda et al. 2012).

$\mathrm{P}$ deficiency also affects the intrinsic nutrient utilization efficiency and dynamics of other nutrients such as nitrogen (N) inside the plants (Israel and Rufty 1988, Fleisher et al. 2012, Singh et al. 2014, Singh and Reddy 2015). An increased tissue $\mathrm{N}$ concentration and $\mathrm{N} / \mathrm{P}$ ratio of plant organs including seeds in P-deficient soybean have been reported and was attributed to a greater $\mathrm{N}$ uptake and storage by plants (Singh et al. 2014). Moreover, P deficiency has been shown to increase plant tissue P-utilization efficiency for photosynthesis and biomass production under optimal temperature regime (Cure et al. 1988, Singh et al. 2014). However, effects of nonoptimal temperatures on the tissue P-utilization efficiency of soybean photosynthetic processes are unclear.

Temperature and precipitation are among the most important environmental drivers that control the crop's agroecological distribution and productivity. Both of these factors have been strongly affected by the alterations in the global climate, which are most likely caused by greenhouse gas emissions and land use changes (Stocker et al. 2013). The global mean surface air temperature is most likely to rise $>1.5^{\circ} \mathrm{C}$ by the end of $21^{\text {st }}$ century, and this will have

$\overline{\text { Received }} 5$ April 2017, accepted 12 September 2018.

+Corresponding author; phone: +1301-504-6633, fax: +1301-504-5823, e-mail: shardendu.singh@ars.usda.gov, singhsk@uw.edu.

Abbreviations: $\mathrm{Chl}$ - chlorophyll; CMT - cell membrane thermostability; $g_{\mathrm{m}}$ - mesophyll conductance; $g_{\mathrm{s}}-$ stomatal conductance; NUE - nitrogen-utilization efficiency; $P_{\mathrm{N}}$ - net photosynthetic rate; PUE - phosphorus-utilization efficiency; SPAD value - an indicator of chlorophyll content, $\mathrm{V}_{\mathrm{Cmax}}$ - maximal rate of carboxylation, $\Phi_{\mathrm{CO} 2}-$ quantum yield of $\mathrm{CO}_{2}$ fixation; $\Phi_{\mathrm{PSII}}$ - photochemical quantum yield of PSII.

Acknowledgments: Authors thank Emily Morris, Jackson Fisher, and Darryl Baxam for help in maintaining the growth chambers. Thanks also goes to the visitors form the Republic of Korea Seunghwan Wi, Agricultural Institute of Climate Change and Sang Wangyu, National Institute of Crop Science for assisting in the measurements. 
strong impacts on the productivity of most crops including soybean (Lobell and Asner 2003, Stocker et al. 2013). In addition, $\mathrm{P}$ deficiency limits crop production worldwide and its limited availability, as a natural resource, is of a global concern (Cordell et al. 2009). Therefore, the availability of plant nutrients will become increasingly important due to the depletion from agricultural lands over multiple years of cultivation, and higher crop nutrient demand due to increased productivity using hybrid cultivars and by the projected rise in atmospheric $\mathrm{CO}_{2}$ concentration (Rogers et al. 1993, Römheld and Kirkby 2010).

Plant photosynthesis contributes to much of plant biomass accumulation and is highly sensitive to levels of $\mathrm{P}$ fertilization and temperature regimes (Taub 2010, Singh and Reddy 2015, Xu et al. 2016). P is an essential part of the cellular membranes, nucleic acid and is directly involved in the carbohydrate metabolism (Marschner 1995, Warren 2011, Singh and Reddy 2015). Most of the prior investigations on crop response to nonoptimal temperatures have often been done under adequate nutrient fertilization (Sinclair 1992). However, under natural growing conditions, crops such as soybean are simultaneously exposed to nonoptimal temperature and nutrient-limited conditions (Sinclair 1992, Mittler 2006). Therefore, it is imperative to understand the interactive effects of $\mathrm{P}$ and $\mathrm{T}$ on soybean physiology.

Soybean growth and physiological processes strongly correlate with the foliar P concentrations or with the growing temperatures (Cure et al. 1988, Campbell et al. 1990, Singh et al. 2014, Singh and Reddy 2015). Sinclair (1992) suggested that effects of environmental factors on plant productivity might be minimized under the nutrient-limited conditions. For instance, studies have shown that soybean $P_{\mathrm{N}}$ response to environmental factors such as elevated $\mathrm{CO}_{2}$ concentration closely depends on the $\mathrm{P}$ fertilization of plants (Cure et al. 1988, Singh et al. 2014, Singh and Reddy 2016). Furthermore, P fertilizer application partly mitigated the adverse effects of drought in soybean grown under $\mathrm{P}$ deficiency (Jin et al. 2006), whereas $\mathrm{N}$ fertilization did not alleviate the negative impacts of heat stress on wheat (Triticum aestivum L.) (Mitchell et al. 1993). Thus, plant response to environmental factors appears to vary depending on the unique combination of stresses. The nature of plant physiological alterations and their magnitude and direction due to $\mathrm{P} \times \mathrm{T}$ interaction is yet to be investigated. Since soybean growth and physiological processes are highly related to the $\mathrm{P}$ fertilization, we hypothesize that their response to $\mathrm{P}$ nutrition will vary when grown under different temperature regimes. The objective of this study was to evaluate the impacts of $\mathrm{P} \times$ $\mathrm{T}$ interaction on soybean photosynthesis and chlorophyll (Chl) fluorescence traits, nutrient-utilization efficiency, cell membrane thermostability, and the dynamics of leaf $P$ and $\mathrm{N}$ concentration.

\section{Materials and methods}

Experimental conditions and plant culture: An experiment was conducted outdoors in the sunlit Soil-PlantAtmosphere-Research (SPAR) chambers at the USDA-
ARS facility in Beltsville, MD, USA. Each SPAR chamber consists of a steel soilbin ( $1 \mathrm{~m}$ deep, $2 \mathrm{~m}$ long, $0.5 \mathrm{~m}$ wide) for plant root growth sealed to a Plexiglas chamber (2.5 m tall, $2.2 \mathrm{~m}$ long, $1.4 \mathrm{~m}$ wide) to accommodate aerial plant parts and atmospheric conditions, a heating and cooling system, and an environmental monitoring and control system. Plexiglas transmits $>90 \%$ of the ambient solar radiation inside the SPAR chambers (Kim et al. 2007). The details of the SPAR chambers and methods of operation and monitoring have been described previously (Fleisher et al. 2009, Timlin et al. 2017). In brief, the temperature is controlled by cooling and heating of the air inside chambers. Chilled ethylene glycol is supplied to the cooling system via solenoid valves depending on the cooling requirements. Electrical resistance heaters provide pulses of heat, as needed, to fine-tune the air temperature. The air passes over the cooling coil and heating elements through the top portion inside the chamber with a sufficient velocity to cause leaf flutter $\left(2.5 \mathrm{~m} \mathrm{~s}^{-1}\right)$ and returns to the air-handling unit just above the soil level. Each chamber is equipped with an infrared gas analyzer (LI-6262, LI-COR Inc., NE, Lincoln, USA) and gas mass flow controller (FM-766, Omega Engineering Inc., Norwalk, CT, USA) to measure and control $\mathrm{CO}_{2}$ inside the SPAR chambers. The continuous monitoring and control of all-important environmental variables in each chamber are done by a dedicated microcomputer workstation using a custom program (Baker et al. 2004, Fleisher et al. 2009).

Soybean [Glycine $\max (\mathrm{L}$.$) Merr., cv. NC-Roy) was$ planted in nine rows $(20 \mathrm{~cm}$ apart, five plants/row) in the soilbin of eight SPAR chambers filled with the mixture of $75 \%$ sand and $25 \%$ vermiculite on 17 June 2015. After emergence (i.e., six days after planting), the treatments were initiated by setting each SPAR chamber to one of the four day/night temperatures $(\mathrm{T})$ at below optimum $\left(24 / 18^{\circ} \mathrm{C}\right)$, optimum $\left(28 / 22^{\circ} \mathrm{C}, \mathrm{OT}\right)$, and two warmer than OT $\left(32 / 26^{\circ} \mathrm{C}\right.$ and $\left.36 / 30^{\circ} \mathrm{C}\right)$, and one of the two concentrations of phosphorus (P) nutrition at $0.5 \mathrm{mM}$ (sufficient) and 0.08 $\mathrm{mM}$ (deficient). A modified Hoagland's nutrient solution was supplied as the fertigation (Hewitt 1952) 4-6 times per day in excess of daily water demand. Water drained through outlets at the bottom of each soilbin. The daytime temperature was initiated at sunrise and returned to the nighttime temperature one hour after sunset resulting in 16-h/8-h day/night thermo-period. The seasonal average daily mean air temperature inside the SPAR chambers was almost the same as the treatment set point at $22 \pm$ $0.13^{\circ} \mathrm{C}, 26.1 \pm 0.12^{\circ} \mathrm{C}, 29.9 \pm 0.14^{\circ} \mathrm{C}$, and $33.8 \pm 0.12^{\circ} \mathrm{C}$ for the below OT, OT, and warmer temperature treatments, respectively, across the $\mathrm{P}$ nutrition. The SPAR chamber $\mathrm{CO}_{2}$ was maintained at $420 \pm 13 \mu \mathrm{mol} \mathrm{mol}^{-1}$ during the daytime and the relative humidity varied between 46 and $68 \%$ during the experiment. A destructive plant harvest was conducted at $29 \mathrm{~d}$ after planting to avoid plant competition by removing two alternate plants form the middle of all rows for all chambers. Thus, after this date, there were nine rows with three plants each $\left(27\right.$ plants $\left.\mathrm{m}^{-2}\right)$ in a given treatment during the measurements of the physiological traits.

Photosynthesis and Chl fluorescence: The photosyn- 
thesis parameters and $\mathrm{Chl}$ fluorescence $(\mathrm{CF})$ were measured simultaneously $36-37 \mathrm{~d}$ after planting on the uppermost fully expanded soybean leaves between 9:00 and 13:00 $\mathrm{h}$ from 3-4 plants in each treatment using a portable photosynthesis system (LI-COR-6400XT, LI-COR Inc., Lincoln, NE, USA) equipped with an integrated fluorescence chamber head (LI-COR 6400-40 leaf chamber fluorometer). The photosynthesis was measured at the PAR of $1,500 \mu \mathrm{mol}$ (photon) $\mathrm{m}^{-2} \mathrm{~s}^{-1}$. The $L I-6400 X T$ cuvette leaf temperature was set to match the treatment daytime temperature, the $\mathrm{CO}_{2}$ concentration was controlled at $400 \mu \mathrm{mol} \mathrm{mol}{ }^{-1}$, and the relative humidity varied between 45 and $60 \%$. The $P_{\mathrm{N}}$ and the steady-state $\mathrm{CF}\left(\mathrm{F}_{\mathrm{s}}\right)$ measurements were taken when a steady state (around 4-6 min) was obtained. The maximal fluorescence $\left(\mathrm{F}_{\mathrm{m}}{ }^{\prime}\right)$ was measured using Multiphase Flash Protocol (MPF) by setting the ramp to $20 \%$, phases 1 to 3 varied between 250 and $300 \mathrm{~ms}$, and the flash intensity was set to nine that yielded the flash between 7,700 and 8,100 $\mu$ mol(photon) $\mathrm{m}^{-2} \mathrm{~S}^{-1}$ among the measurements. These settings were obtained based on pretests the authors conducted on a representative soybean leaf across treatments. In the lightadapted leaves, the photochemical quantum yield of PSII $\left(\Phi_{\text {PSII }}\right)$ was determined following Maxwell and Johnson (2000) using the equation $\Phi_{\text {PSII }}=\left(\mathrm{F}_{\mathrm{m}}{ }^{\prime}-\mathrm{F}_{\mathrm{s}}\right) / \mathrm{F}_{\mathrm{m}}{ }^{\prime}$. These parameters along with stomatal conductance to water vapor $\left(g_{\mathrm{s}}\right)$ and $\mathrm{CO}_{2}\left(g_{\mathrm{sCO} 2}\right)$, substomatal $\mathrm{CO}_{2}$ concentration $\left(C_{\mathrm{i}}\right)$, and quantum yield of $\mathrm{CO}_{2}$ assimilation $\left(\Phi_{\mathrm{CO} 2}\right)$ were computed using the instrument software (LI-COR 6400XT Instruction Manual, version 6).

Mesophyll conductance, maximal carboxylation rate, and photosynthetic limitations: The mesophyll conductance $\left(g_{\mathrm{m}}\right)$ and the maximum carboxylation rate $\left(\mathrm{V}_{\mathrm{Cmax}}\right)$ were determined $38 \mathrm{~d}$ after planting according to Bunce (2009) and described by Singh and Reddy (2016). This method is based on the oxygen sensitivity of the Rubisco in the chloroplast. The $g_{\mathrm{m}}$ and $\mathrm{V}_{\mathrm{Cmax}}$ were determined by measuring the response of photosynthesis to two different $\mathrm{O}_{2}$ concentrations (ambient 21\% and low 2\%) under the strictly Rubisco-limited state as described by Singh and Reddy (2016). The $g_{\mathrm{m}}$ and $\mathrm{V}_{\mathrm{Cmax}}$ were estimated iteratively by PROC NLIN procedure in SAS using a statistical analysis program given by Singh and Reddy (2016) where the day-time leaf respiration rate was set to $2.0 \mu \mathrm{mol}\left(\mathrm{CO}_{2}\right) \mathrm{m}^{-2} \mathrm{~s}^{-1}$ based on the previous report indicating the averaged day respiration value near this level in the same cultivars and at the similar range of temperature treatments (Xu et al. 2016). The input coefficients including the Michaelis-Menten constants of Rubisco for $\mathrm{CO}_{2}\left(\mathrm{~K}_{\mathrm{c}}\right)$ and $\mathrm{O}_{2}\left(\mathrm{~K}_{\mathrm{o}}\right)$, respectively, and the temperature corrected chloroplast-based $\mathrm{CO}_{2}$-compensation point $\left(\Gamma^{*}\right)$ were based on Sharkey et al. (2007). Briefly, the $P_{\mathrm{N}}$ at the two $\mathrm{O}_{2}$ concentrations in the uppermost fully expanded leaves of 3-4 plants were measured similarly as described previously for the photosynthetic measurements except for the $\mathrm{CO}_{2}$ concentration in the instrument leaf chamber that was set to $250 \mu \mathrm{mol} \mathrm{mol}{ }^{-1}$. The $P_{\mathrm{N}}$ was first measured at the ambient $\mathrm{O}_{2}$ concentration followed by the $2 \% \mathrm{O}_{2}$ in the same leaf. To realize the low $\mathrm{O}_{2}$, a gas cylinder containing
$2 \% \mathrm{O}_{2}$ and $98 \% \mathrm{~N}_{2}$ was connected to the LI-COR $6400 X T$ inlet after passing through a rotometer to adjust the flow rate to a constant level. The sensitivity of the infrared gas analyzer to $\mathrm{O}_{2}$ was corrected before recording the data by changing the $\mathrm{O}_{2}$ concentration in the instrument software.

The estimation of stomatal $\left(\mathrm{L}_{\mathrm{S}}\right)$, mesophyll $\left(\mathrm{L}_{\mathrm{M}}\right)$, and biochemical $\left(\mathrm{L}_{\mathrm{B}}\right)$ limitations to photosynthesis was conducted based on the relative changes in the $P_{\mathrm{N}}$ that is expressed in the terms of relative changes in the $g_{\mathrm{sCO} 2}, g_{\mathrm{m}}$, and $\mathrm{V}_{\mathrm{Cmax}}$ as proposed by Jones (1985) and extended by Grassi and Magnani (2005) using the equations:

$$
\begin{aligned}
& \mathrm{L}_{\mathrm{S}}=\frac{\left(g_{\text {tot }} / g_{\mathrm{s} C \mathrm{C} 2}\right) \times\left(\partial P_{\mathrm{N}} / \partial C_{\mathrm{c}}\right)}{g_{\text {tot }}+\left(\partial P_{\mathrm{N}} / \partial C_{\mathrm{c}}\right)} \times 100 \\
& \mathrm{~L}_{\mathrm{M}}=\frac{\left(g_{\text {tot }} / g_{\mathrm{m}}\right) \times\left(\partial P_{\mathrm{N}} / \partial C_{\mathrm{c}}\right)}{g_{\text {tot }}+\left(\partial P_{\mathrm{N}} / \partial C_{\mathrm{c}}\right)} \times 100 \\
& \mathrm{~L}_{\mathrm{B}}=\frac{\mathrm{g}_{\text {tot }}}{g_{\text {tot }}+\left(\partial P_{\mathrm{N}} / \partial C_{\mathrm{c}}\right)} \times 100
\end{aligned}
$$

where $g_{\text {tot }}$ is the total conductance to $\mathrm{CO}_{2}$ between leaf surface to carboxylation site $\left(1 / g_{\text {tot }}=1 / g_{s C O 2}+1 / g_{\mathrm{m}}\right)$. The $C_{\mathrm{c}}$ was calculated as $C_{\mathrm{i}}-P_{\mathrm{N}} / g_{\mathrm{m}}$. The $\partial P_{\mathrm{N}} / \partial C_{\mathrm{c}}$ was calculated according to Sanglard et al. (2014) using the equation below:

$\frac{\partial P_{\mathrm{N}}}{\partial C_{\mathrm{c}}}=\frac{\mathrm{V}_{\mathrm{C} \max } \times\left(\Gamma^{*}+\mathrm{K}_{\mathrm{m}}\right)}{\left(C_{\mathrm{c}}+\mathrm{K}_{\mathrm{m}}\right)^{2}}$

where the $\mathrm{K}_{\mathrm{m}}$ was calculated as $\mathrm{K}_{\mathrm{c}}\left(1+\mathrm{O} / \mathrm{K}_{\mathrm{o}}\right)$, $\mathrm{O}$ is the ambient oxygen concentration.

SPAD value and cell membrane thermostability: The measurement of the SPAD value (an indicator of $\mathrm{Chl}$ content), was made on the same leaves, which were used for the photosynthetic measurements. The SPAD value was measured using a SPAD 502 Plus Chlorophyll Meter (Spectrum Technologies Inc., Aurora, IL, USA) at three locations on each leaf and the averaged value was recorded.

The cell membrane thermostability (CMT) of the uppermost fully expanded leaves in 3-4 plants per treatment was assessed on $37 \mathrm{~d}$ after planting according to Martineau et al. (1979). In brief, four leaf disks $\left(0.95 \mathrm{~cm}^{-2}\right)$ from each plant were prepared in two sets (C-set and T-set) of test tubes containing $10 \mathrm{ml}$ of de-ionized water after washing thoroughly to remove the electrolytes adhering at the cut surface of disks. Test tubes were covered with the aluminum foil. Thereafter, the T-set received a 20-min water-bath treatment of $50^{\circ} \mathrm{C}$ while the $\mathrm{C}$-set tubes were kept at ambient temperature during this time. An initial electrical conductivity reading of the solution of both sets (C1 and T1) was taken using a conductivity meter (Corning Checkmate II, Corning Inc., New York, NY, USA) after keeping them overnight in a cold room set at $18^{\circ} \mathrm{C}$ air temperature. Thereafter, to kill leaf tissue completely, both sets were autoclaved at $120^{\circ} \mathrm{C}$ and 0.15 $\mathrm{MPa}$ for $20 \mathrm{~min}$, and the final electrical conductivity readings ( $\mathrm{C} 2$ and $\mathrm{T} 2$ ) were made after tubes were cooled to the room temperature. The CMT was calculated using the equation based on Martineau et al. (1979) as: 
CMT $(\%)=\frac{1-\left(\frac{\mathrm{T} 1}{\mathrm{~T} 2}\right)}{1-\left(\frac{\mathrm{C} 1}{\mathrm{C} 2}\right)} \times 100$

Tissue phosphorus and nitrogen concentration: The leaves were detached after the photosynthetic measurements to determine the individual leaf area, dry mass, and tissue phosphorus $(\mathrm{P})$ and nitrogen $(\mathrm{N})$ concentration. The leaves were dried in an oven at $70^{\circ} \mathrm{C}$ until constant mass and the dried material was ground using a Wiley Mill (Wiley ${ }^{\circledR}$ Mill, Thomas Scientific, Swedesboro, NJ, USA) to pass through a 1-mm screen. The P concentration of the dried material was determined at the Agriculture Diagnostic Laboratory, University of Arkansas, Fayetteville, AR, USA, using a standard procedure (Plank 1992). The N concentration of the dried material was determined by combustion using a CHN-2000 (Carbon Hydrogen Nitrogen-2000, LECO Corporation, Saint Joseph, MI, USA). The P and N utilization efficiency (PUE and NUE, respectively) for $P_{\mathrm{N}}$, $\mathrm{V}_{\mathrm{Cmax}}$, and $\Phi_{\mathrm{PSII}}$ was estimated by dividing with the value of tissue $\mathrm{P}$ or $\mathrm{N}$ concentration based on leaf area $\left(\mathrm{mg} \mathrm{m}^{-2}\right)$ of the same leaf.

Data analysis: A prior uniformity study using the same chambers indicated that no statistical differences were present for the plant growth between the SPAR chambers (Fleisher et al. 2009). Therefore, to test for the effect of treatments and their interaction on the measured traits, PROC MIXED procedure of the SAS (SAS Enterprise Guide, 4.2, SAS Institute Inc., Cary, NC, USA) with Kenward-Rogers (kr) adjustment of degrees of freedom was used for analysis of variance ( $A N O V A$ ) using individual plants as pseudoreplicates. The $A N O V A$ significance levels ( $P$-values) are presented at the significance level $\alpha=0.05$ is presented. The regression analysis was conducted using PROC GLM procedure of SAS.

\section{Results}

Tissue constituents and CMT: The leaf $\mathrm{P}$ concentration significantly declined $40-60 \%$ while the $\mathrm{N}$ concentration and N/P ratio increased $4-22 \%$ and $88-166 \%$, respectively, in the P-deficient $v s$. P-sufficient leaves across $\mathrm{T}$ treatments (Fig. $1 A-C$ ). However, these traits along with the Chl content did not show a significant effect of $\mathrm{T}$ (Fig. $1 C)$. There was significant $\mathrm{P} \times \mathrm{T}$ interaction for SPAD value and CMT (Fig. $1 D, E$ ). The P deficiency decreased $(\approx 21 \%)$ the Chl content, particularly, below and at the OT $\left(22\right.$ and $\left.26^{\circ} \mathrm{C}\right)($ Fig. $1 D)$. The $\mathrm{P}$ deficiency increased CMT by $25.8 \%$ at $22^{\circ} \mathrm{C}$, but it either did not affect at OT or decreased $16-18 \%$ at warmer T (Fig. $1 E$ ). Moreover, the warmer than OT decreased CMT, especially, in the P-deficient leaves.

Photosynthetic parameters: There was a significant $\mathrm{P} \times \mathrm{T}$ interaction for $P_{\mathrm{N}}$ and $g_{\mathrm{s}}$ (Fig. $2 A, B$ ). Relative to sufficient $\mathrm{P}$ nutrition, the $P_{\mathrm{N}}$ declined 47 and $36 \%$ under $\mathrm{P}$ deficiency at 22 and $26^{\circ} \mathrm{C}$, respectively, but remained almost similar at the warmer T treatments (Fig. $2 A$ ). Relative to the OT, the $P_{\mathrm{N}}$ slightly declined by $5-9 \%$ at colder and warmer T under sufficient $\mathrm{P}$, however, it was either $21 \%$ smaller at below OT or $43 \%$ greater at warmer than OT under the P-deficient condition (Fig. 2A). The $g_{\mathrm{s}}$ also declined $34-55 \%$ under $\mathrm{P}$ deficiency, especially, at and below the OT (Fig 2B). In contrast, $g_{\mathrm{s}}$ increased as temperature increased up to the two warmest treatments, particularly, in the P-deficient leaves (Fig. $2 B$ ). Under $\mathrm{P}$ deficiency, the $\mathrm{V}_{\mathrm{Cmax}}$ decreased $36-50 \%$ at and below the OT but showed similar values at warmer $\mathrm{T}$ (Fig. $2 C$ ). The $\mathrm{V}_{\mathrm{Cmax}}$ also increased with the $\mathrm{T}$ across both $\mathrm{P}$ nutrition (Fig. $2 C$ ). Under P deficiency, the $g_{\mathrm{m}}$ was $24-42 \%$ smaller across $\mathrm{T}$ treatments and showed the greatest value at the warmest $\mathrm{T}$ treatment (Fig. 2D).

Chl fluorescence parameters: There was a significant $\mathrm{P} \times \mathrm{T}$ interaction for $\Phi_{\mathrm{CO} 2}$ and $\Phi_{\mathrm{PSII}}$ exhibiting a consistent decline by $33-48 \%$ under $P$ deficiency at and below the OT but not at the warmer temperatures (Fig. $3 A-B$ ). These parameters also increased as the $\mathrm{T}$ increased, especially in the P-deficient leaves. The $\Phi_{\mathrm{PSII}} / \Phi_{\mathrm{CO} 2}$ was not affected by the $\mathrm{P}$ treatment but increased $\approx 18 \%$ at the warmest $\mathrm{T} v \mathrm{~s}$. OT (Fig. 3C).

The stomatal, mesophyll, and biochemical limitations to $\boldsymbol{P}_{\mathrm{N}}$ : A significant effect of T was observed for $\mathrm{L}_{\mathrm{S}}$ and $\mathrm{L}_{\mathrm{M}}$ (Fig. 4A,B). Relative to the OT, the $\mathrm{L}_{\mathrm{S}}$ slightly declined by $11-15 \%$ at colder and warmer $\mathrm{T}$ under $\mathrm{P}$ deficiency, however, it was either $18-23 \%$ smaller at below OT and at $30^{\circ} \mathrm{C}$ (daily mean $\mathrm{T}$ ) or $18 \%$ greater at the warmest $\mathrm{T}$ under sufficient $\mathrm{P}$ condition (Fig. $4 A$ ). Relative to the OT, the $\mathrm{L}_{\mathrm{M}}$ was almost similar at the colder $\mathrm{T}$ but either increased by $45 \%$ at $30^{\circ} \mathrm{C}$ (daily mean $\mathrm{T}$ ) or decreased by $18 \%$ at the warmest $\mathrm{T}$, when averaged between $\mathrm{P}$ concentrations (Fig. 4B). The effects of treatments for $\mathrm{L}_{\mathrm{B}}$ was not statistically significant (Fig. 4C).

Relationship of $\mathrm{Chl}$ content with leaf $\mathrm{N}$, photosynthesis, and $\mathrm{Chl}$ fluorescence parameters: There were significant curvilinear regression relationships of SPAD value with the leaf $\mathrm{N}$ concentration, $P_{\mathrm{N}}$, and $\Phi_{\mathrm{PSII}}$ (Fig. 5). A single polynomial second order function across the treatments $(\mathrm{P}$ and $\mathrm{T})$ best described their regression relationships for each parameter. The leaf $\mathrm{N}$ concentration tended to decrease while $P_{\mathrm{N}}$, and $\Phi_{\mathrm{PSII}}$ increased curvilinearly as the Chl content increased (Fig. 5).

Nutrient-utilization efficiency: The main effect of treatments (P and T) was significant for PUE and NUE of photosynthetic and Chl fluorescence parameters (Fig. 6). The PUE of $P_{\mathrm{N}}, \mathrm{V}_{\mathrm{Cmax}}$, and $\Phi_{\mathrm{PSII}}$ was greater under $\mathrm{P}$ deficiency across temperature regimes, except at the lowest temperature, with the highest increases (90-133\%) observed under the warmer than OT (Fig. 6A-C). In contrast, the NUE of these parameters was smaller under $\mathrm{P}$ deficiency across temperatures with the greatest decrease $(27-62 \%$ ) found below or at the OT (Fig. $6 D-F)$. Several of these parameters also had a significant $\mathrm{P} \times \mathrm{T}$ interaction exhibiting a distinct temperature response pattern between the two P nutrition. For example, the PUE of $P_{\mathrm{N}}, \mathrm{V}_{\mathrm{Cmax}}$, and $\Phi_{\text {PSII }}$ almost consistently increased with temperature under $\mathrm{P}$ deficiency but varied under the sufficient $\mathrm{P}$ (Fig. 6A-D). 

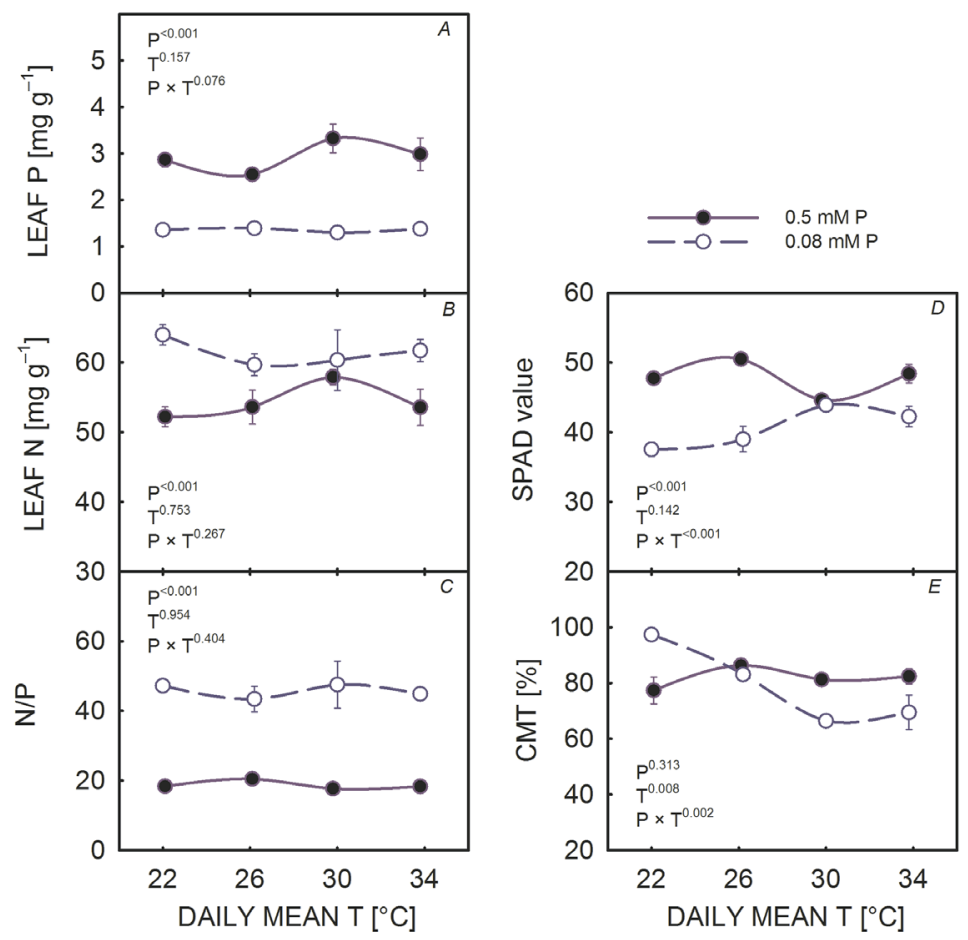

Fig. 1. Response of the tissue $(A)$ phosphorus $(\mathrm{P})$ and $(B)$ nitrogen $(\mathrm{N})$ concentrations, $(C) \mathrm{N} / \mathrm{P}$ ratio, $(D)$ SPAD value, and $(E)$ cell membrane thermostability (CMT) to temperature $(\mathrm{T})$ in the uppermost fully expanded leaves of soybean grown under two phosphorus $(\mathrm{P})$ nutrition. Symbols represent the mean \pm standard error $(n=3-4)$. Error bars smaller than the symbol are not visible. The significance level ( $P$-value) of the analysis of variance for the effect of treatments and their interaction $(\mathrm{P}, \mathrm{T}$, $\mathrm{P} \times \mathrm{T})$ is also shown.
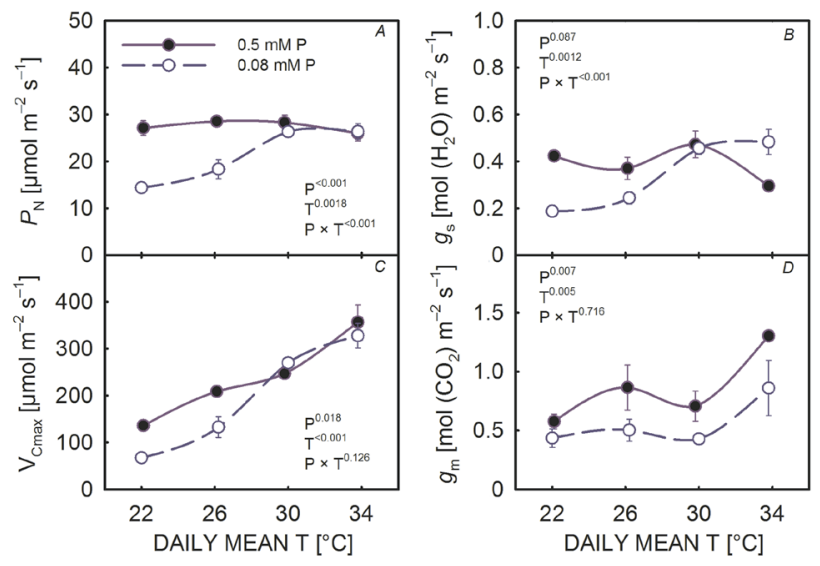

Fig. 2. Response of the $(A)$ photosynthetic rate $\left(P_{\mathrm{N}}\right),(B)$ maximal rate of carboxylation $\left(\mathrm{V}_{\mathrm{Cmax}}\right),(C)$, stomatal conductance $\left(g_{\mathrm{s}}\right)$, and $(D)$ mesophyll conductance $\left(g_{\mathrm{m}}\right)$ to temperature $(\mathrm{T})$ in the uppermost fully expanded leaves of soybean grown under two phosphorus $(\mathrm{P})$ nutrition. Symbols represent the mean \pm standard error $(n=3-4)$. Error bars smaller than the symbol are not visible. The significance level ( $P$-value) of the analysis of variance for the effect of treatments and their interaction $(\mathrm{P}, \mathrm{T}, \mathrm{P} \times \mathrm{T})$ is also shown.

A similar pattern was also observed for the NUE of $P_{\mathrm{N}}$, and $\Phi_{\text {PSII }}$ (Fig. 6D,F).

\section{Discussion}

In this study, the interactive impacts of temperature and $\mathrm{P}$ nutrition on soybean physiological traits were investigated. Results showed that P deficiency adversely affected soybean physiological traits primarily at and below the OT. However, under warmer than optimum

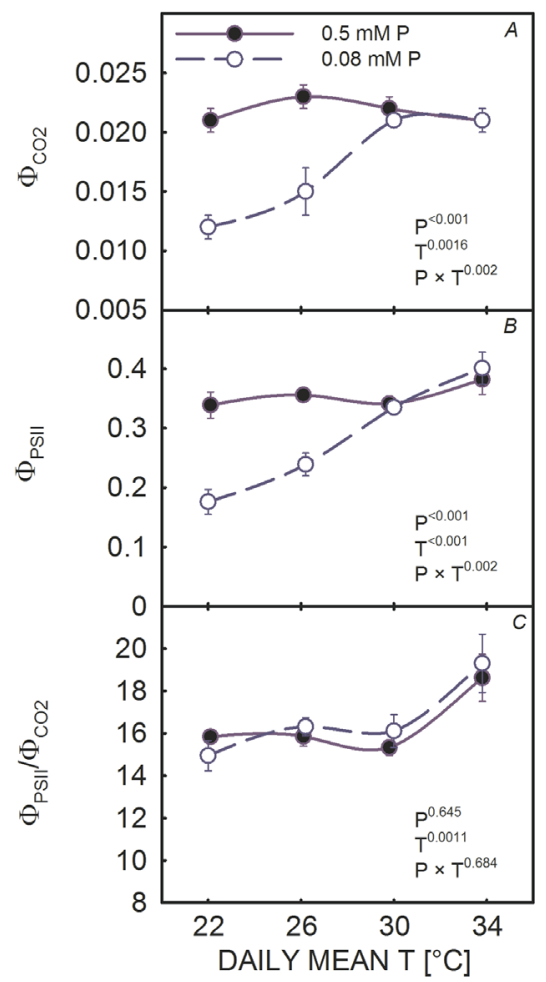

Fig. 3. Response of the $(A)$ quantum yield of $\mathrm{CO}_{2}$ fixation ( $\mathrm{CO}_{2}$ ), $(B)$ photochemical quantum yield of PSII $\left(\Phi_{\mathrm{PSII}}\right)$, and $(C) \Phi_{\mathrm{PSII}} /$ $\Phi_{\mathrm{CO} 2}$ ratio to temperatures $(\mathrm{T})$ in the uppermost fully expanded leaves of soybean grown under two phosphorus $(\mathrm{P})$ nutrition. Symbols represent the mean \pm standard error $(n=3-4)$. Error bars smaller than the symbol are not visible. The significance level $(P$-value $)$ of the analysis of variance for the effect of treatments and their interaction $(\mathrm{P}, \mathrm{T}, \mathrm{P} \times \mathrm{T})$ is also shown. 


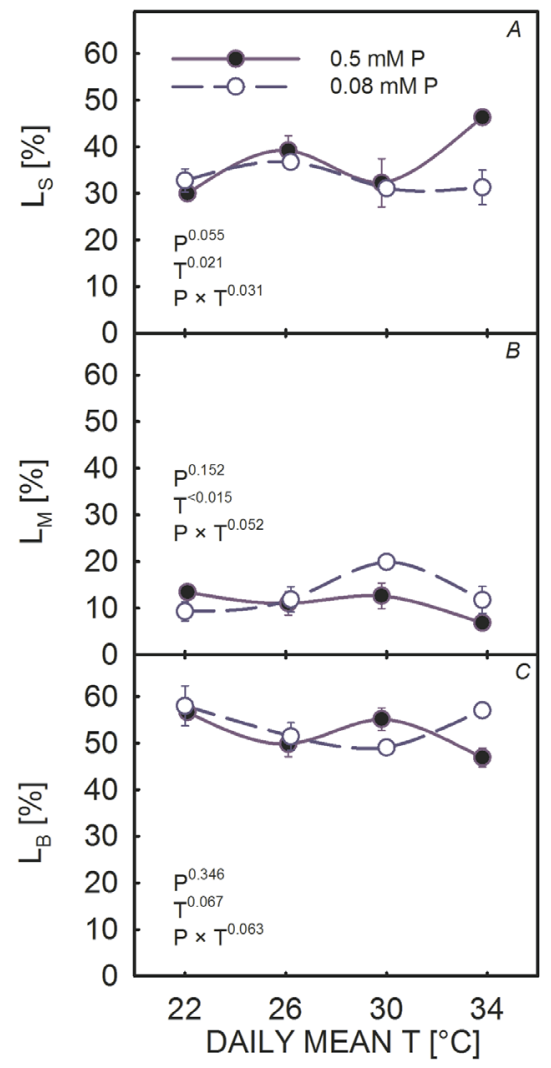

Fig. 4. Response of $(A)$ stomatal $\left(\mathrm{L}_{\mathrm{S}}\right),(B)$ mesophyll $\left(\mathrm{L}_{\mathrm{M}}\right)$, and $(C)$ biochemical $\left(\mathrm{L}_{\mathrm{B}}\right)$ limitations to photosynthesis in the uppermost fully expanded leaves of soybean grown under two phosphorus (P) nutrition. Symbols represent the mean \pm standard error $(n=3-4)$. Error bars smaller than the symbol are not visible. The significance level ( $P$-value) of the analysis of variance for the effect of treatments and their interaction $(\mathrm{P}, \mathrm{T}, \mathrm{P} \times \mathrm{T})$ is also shown.

temperature regimes in P-deficient plants, soybean was able to maintain photosynthetic processes $\left(\right.$ e.g., $P_{\mathrm{N}}, \mathrm{V}_{\mathrm{Cmax}}$, SPAD value, $\left.\Phi_{\text {PSII }}\right)$ close to the values observed under sufficient $\mathrm{P}$ fertilization, exhibiting a distinctive response. Furthermore, P-deficient plants also exhibited lower stomatal limitation to $P_{\mathrm{N}}$ and markedly higher $\mathrm{P}$ and $\mathrm{N}$ utilization efficiencies at warmer than OT regimes. Thus, the hypothesis that "plant response to P nutrition will vary when grown under different temperature regimes" was largely validated.

Tissue $\mathbf{P}$ and $\mathbf{N}$ concentrations: Relative to P-sufficient condition, under the $\mathrm{P}$ deficiency, leaf $\mathrm{P}$ concentration declined over $50 \%$ averaged across temperature, but the $\mathrm{N}$ concentration increased over $13 \%$. Similar changes in the foliar $\mathrm{P}$ and $\mathrm{N}$ concentrations in $\mathrm{P}$-deficient plants have been reported previously, and the increased tissue $\mathrm{N}$ might be attributed to the excess absorption via roots as it was not limiting in the nutrient solution (Fleisher et al. 2012, Singh et al. 2014). Under P-limiting conditions, excess $\mathrm{N}$ in leaf tissues is often stored as nonfunctional protein and nitrogenous compounds such as amino acids (Israel and Rufty 1988, Staswick et al. 1991). Although there

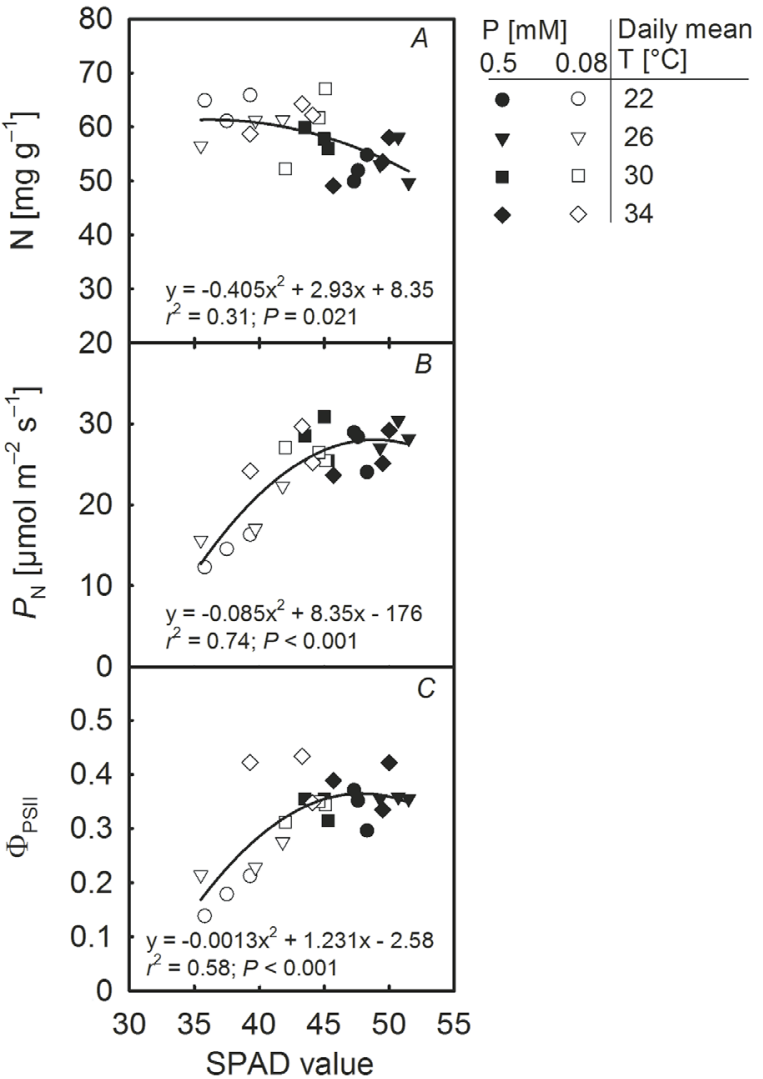

Fig. 5. The regression relationship of SPAD value with $(A)$ nitrogen concentration $(\mathrm{N}),(B)$ photosynthetic rate $\left(P_{\mathrm{N}}\right)$, and $(C)$ photochemical quantum yield of PSII $\left(\Phi_{\mathrm{PSII}}\right)$ in the uppermost fully expanded leaves of soybean grown under four temperature (T) regimes and two phosphorus $(\mathrm{P})$ nutrition. Symbols represent the individual plant. The line represents the fit of "polynomial second order function" and coefficients of the regression equation is also given. The significance level $(P$-value) of the regression relationship is also shown.

were slight increases in the leaf $\mathrm{P}$ and $\mathrm{N}$ concentrations at the warmer than OT, the effect of temperature was statistically not significant. However, previous studies suggested an increased tissue $\mathrm{N}$ or $\mathrm{P}$ concentration at warmer temperatures in wheat, especially at the later stages of the development (Manoj et al. 2012). The tissue $\mathrm{N}$ accumulation under $\mathrm{P}$ deficiency resulted into the increased N/P ratio, which is also considered as an indicator of $\mathrm{P}$ limitation to the plant growth (Koerselman and Meuleman 1996, Singh et al. 2014). The observed foliar $\mathrm{P}$ concentration under the sufficient $\mathrm{P}$ fertilization was comparable to the observations made in other studies with soybean (Cassman et al. 1981, Walker et al. 1985).

Photosynthesis processes and nutrient-utilization efficiency: Under $\mathrm{P}$ deficiency, the decreased photosynthetic $\left(P_{\mathrm{N}}, \mathrm{V}_{\mathrm{Cmax}}, g_{\mathrm{s}}, g_{\mathrm{m}}, \Phi_{\mathrm{CO} 2}\right)$ and Chl fluorescence $\left(\Phi_{\mathrm{PSII}}\right)$ parameters observed below and at OT was in agreement with other studies (Cure et al. 1988, Singh and Reddy 2015). A distinct temperature response of $P_{\mathrm{N}}$ between $\mathrm{P}$ treatments was evident due to the $\mathrm{P} \times \mathrm{T}$ interaction. In regards to the $\mathrm{T}$ response, under sufficient 

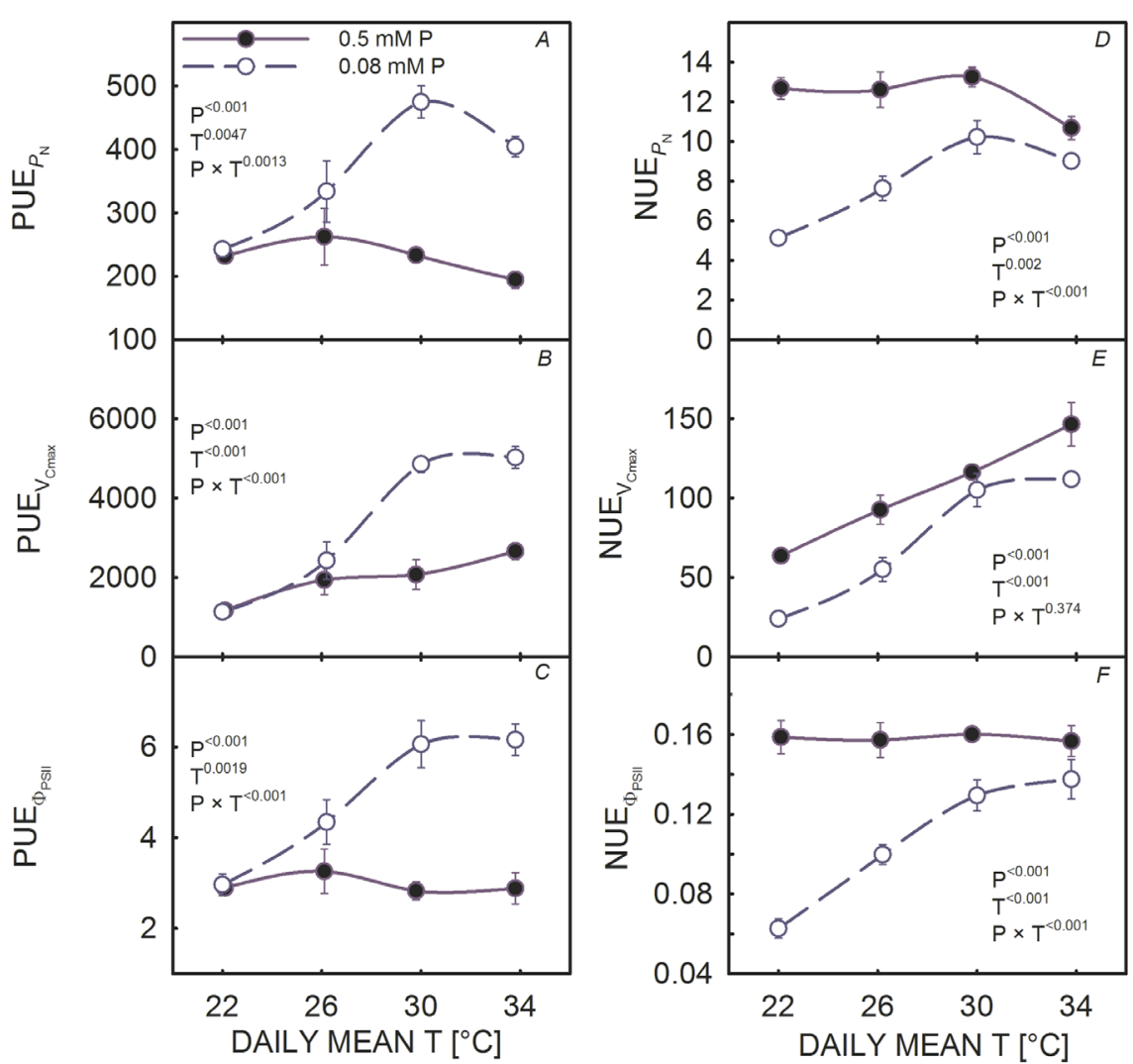

Fig. 6. Response of the phosphorus (PUE) and nitrogen (NUE) utilization efficiencies of $(A, D)$ photosynthetic rate $\left[\mathrm{PUE}_{P \mathrm{~N}}, \mathrm{NUE}_{P \mathrm{~N}} ; \mu \mathrm{mol} \mathrm{mg} \mathrm{m}^{-1}(\mathrm{P}) \mathrm{s}^{-1}\right]$, $(B, E)$ maximal rate of carboxylation

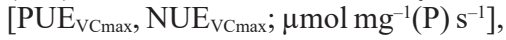
and $(C, F)$ photochemical quantum yield of PSII (PUE ${ }_{\Phi P S I I}$ ) to temperatures (T) in the uppermost fully expanded leaves of soybean grown under two phosphorus (P) nutrition. Symbols represent the mean \pm standard error $(n=3-4)$. Error bars smaller than the symbol are not visible. The significance level ( $P$-value) of the analysis of variance for the effect of treatments and their interaction $(\mathrm{P}, \mathrm{T}$, $\mathrm{P} \times \mathrm{T})$ is also shown.
P content, $P_{\mathrm{N}}$ tended to decrease at below and above OT, which was consistent with the previous studies in soybean grown under well-fertilized conditions (Sionit et al. 1987, Rosenthal et al. 2014, Xu et al. 2016). In contrast, under P-deficient condition, we found that $P_{\mathrm{N}}$ increased with T and had greater values at warmer $\mathrm{T}$ regimes. Remarkably, at warmer than OT in P-deficient plants, $P_{\mathrm{N}}$ was also maintained close to the observation made under sufficient $\mathrm{P}$ fertilization. In fact, this maintained $P_{\mathrm{N}}$ at warmer $\mathrm{T}$ in P-deficient plants was also supported by the sustained $g_{\mathrm{s}}$, $\mathrm{V}_{\mathrm{Cmax}}, \Phi_{\mathrm{CO} 2}, \Phi_{\mathrm{PSII}}$, and SPAD values, suggesting a close association among various photosynthetic processes relating to the $\mathrm{CO}_{2}$ diffusion, carboxylation capacity, photosystem functioning, and Chl. The coregulation of photo-biochemical processes and the $\mathrm{CO}_{2}$ diffusion inside leaves are vital to optimize carbon fixation and might be considered as an acclimation/adaptation strategy of plants under warmer conditions and nutrient-limited environments (Ort and Baker 2002, Singh and Reddy 2018).

The biochemical limitation (i.e., $\mathrm{L}_{\mathrm{B}}$ ) is often the primary cause of the photosynthetic limitations in soybean at and below the OT while restricted $\mathrm{CO}_{2}$ diffusion due to stomatal and mesophyll limitations (i.e., $\mathrm{L}_{\mathrm{S}}$ and $\mathrm{L}_{\mathrm{M}}$ ) play important roles at warmer temperatures under normal conditions (Warren 2008, Xu et al. 2016). Under $\mathrm{P}$-deficient condition, a consistent response to temperatures was observed for the photosynthetic limitations, which was primarily attributed to the $\mathrm{L}_{\mathrm{B}}(49-58 \%)$ followed by $\mathrm{L}_{\mathrm{S}}(31-37 \%)$ and $\mathrm{L}_{\mathrm{M}}(9-20 \%)$. In contrast, under sufficient $\mathrm{P}$ condition, an exception occurred at the warmest $\mathrm{T}$ where $\mathrm{L}_{\mathrm{B}}$ and $\mathrm{L}_{\mathrm{S}}$ were of the similar magnitude $(\approx 46 \%)$ due to a marked increase in $\mathrm{L}_{\mathrm{S}}$ while the $g_{\mathrm{s}}$ declined. Rosenthal et al. (2014) also reported an increased stomatal limitation at warmer than ambient temperature regardless of the changes in $g_{s}$ in soybean grown under well-fertilized condition. In the current study, the $\mathrm{L}_{\mathrm{S}}$ appeared to limit $P_{\mathrm{N}}$ to a smaller extent under P-deficient condition than under P-sufficient, especially at the warmest $\mathrm{T}$ regime. Above OT, an opposite trend between $g_{\mathrm{m}}$ and $\mathrm{L}_{\mathrm{M}}$ was found across $\mathrm{P}$ concentrations suggesting higher the mesophyll conductance lower the $\mathrm{L}_{\mathrm{M}}$. However, an increased $\mathrm{L}_{\mathrm{M}}$ have been reported despite a greater $g_{\mathrm{m}}$ under warmer than optimum temperature regimes in other studies (Warren 2008, Xu et al. 2016). The treatment effects on $\mathrm{L}_{\mathrm{B}}$ was not statistically significant. Moreover, the insignificant impact of $\mathrm{P}$ deficiency on stomatal and mesophyll limitations was in agreement with previous studies in soybean (Singh and Reddy 2016) and tree species (Bown et al. 2009, Warren 2011). Thus, under P deficiency, the $g_{\mathrm{s}}$ and $g_{\mathrm{m}}$ at the warmer temperatures either improved or did not restrict the $\mathrm{CO}_{2}$ diffusion processes, which might have assisted in maintaining the $P_{\mathrm{N}}$ and the carboxylation processes $\left(\mathrm{V}_{\mathrm{Cmax}}\right)$ close to the observation made under $\mathrm{P}$ sufficient condition. The temperature response of $\mathrm{V}_{\mathrm{Cmax}}$ was consistent between $\mathrm{P}$ concentrations and might be considered as an acclimation response of the carboxylation capacity to growing temperatures (Hikosaka et al. 2006, $\mathrm{Xu}$ et al. 2016).

The Chl fluorescence parameters and photosynthetic pigments are used to assess the functional characteristics of the photosystem under stress conditions (van Kooten and Snel 1990, Taiz et al. 2014, Singh and Reddy 
$2015)$. The similar pattern of $\Phi_{\mathrm{CO} 2}$ and $\Phi_{\mathrm{PSII}}$ as of the $P_{\mathrm{N}}$ signified a sustained photochemistry of the chloroplasts and adequate functioning of photochemical reactions at warmer temperatures in P-deficient leaves (Singh and Reddy 2018). In fact, the strong association of the Chl content with the photosynthesis and CF parameters (Fig. 5) also delineated the coregulation of these parameters across the treatments to optimize the structural and functional properties of the PSII. A lower SPAD value (as an indicator of $\mathrm{Chl}$ content) in P-deficient leaves was observed at and below the OT and might be considered as a plant mechanism to minimize light absorption and photodamage of the PSII (Singh and Reddy 2016, 2018). The $\Phi_{\mathrm{PSII}} / \Phi_{\mathrm{CO} 2}$ relationship represents quantum yield of PSII activity vs. the apparent quantum yield of $\mathrm{CO}_{2}$ fixation that indicates the PSII activity per $\mathrm{CO}_{2}$ assimilated (Edwards and Baker 1993, Jacob and Lawlor 1993). The observed increase in $\Phi_{\mathrm{PSII}} / \Phi_{\mathrm{CO} 2}$ ratio at the warmest temperature might be attributed to the consumption of electrons in processes other than $\mathrm{CO}_{2}$ fixation including alternative sinks, such as photorespiration, pseudocyclic electron fluxes, and nitrogen metabolism (Edwards and Baker 1993). Evidence of increased photo-respiration under warmer temperatures have been reported previously (Oberhuber and Edwards 1993, Xu et al. 2016). Despite the lower CMT in P-deficient leaves at the warmer temperatures, an increased $\Phi_{\text {PSII }}$ might suggest a thermal acclimation of cellular membranes in leaves adapted to the long-term warmer temperature regime. The observed lower CMT at warmer than OT might indicate an increased fluidity of cellular membranes and was in agreement with the previous reports (Koti et al. 2007, Zheng et al. 2011). Temperature has a strong influence on the plasma and chloroplast membrane's lipid compositions, and a decreased unsaturation of the cellular membranes under warmer conditions enhances cellular fluidity and thermotolerance where $\mathrm{P}$ requiring phospholipids are replaced by the sugar-containing galactolipids (Murakami et al. 2000, Zheng et al. 2011).

Under P-sufficient condition, intrinsic P-utilization efficiency of $P_{\mathrm{N}}\left(\mathrm{PUE}_{P \mathrm{~N}}\right)$ tended to be lower at below or above the OT. A decreased P-use efficiency of grain yield under the warmer (ambient $+3{ }^{\circ} \mathrm{C}$ ) growing condition has also been reported in wheat (Manoj et al. 2012). In contrast, under $\mathrm{P}$ deficiency, a marked increase in the PUE of photosynthetic process $\left(P_{\mathrm{N}}, \mathrm{V}_{\mathrm{Cmax}}\right.$, and $\left.\Phi_{\mathrm{PSII}}\right)$ under warmer than OT signified plant's ability to better utilize tissue available $\mathrm{P}$. This might suggest a greater investment of the available pool of the tissue $\mathrm{P}$ in the P-containing cellular metabolites (e.g., ATP, NADP) and inorganic phosphate recycling, which play critical role in the energy transfer and photosynthetic processes (Geiger and Servaites 1994, Hidaka and Kitayama 2009). Moreover, the NUE of $P_{\mathrm{N}}$ also increased with temperature, especially, under P-deficient condition, indicating better utilization of the foliar $\mathrm{N}$ under warmer conditions. Thus, both the greater PUE and NUE at warmer temperatures might have also assisted to the observed increases in the leaf photosynthetic potential of soybean grown under P deficiency at warmer conditions.

In summary, physiological traits, such as CMT, SPAD value, $P_{\mathrm{N}}, g_{\mathrm{s}}, \Phi_{\mathrm{PSII}}$, and nutrient-utilization efficiencies, showed $\mathrm{P} \times \mathrm{T}$ interaction, which was attributable to the distinct effects of $\mathrm{P}$ deficiency between the temperature regimes. The $\mathrm{P}$ deficiency limited $P_{\mathrm{N}}$ and other photosynthetic traits, particularly at and below the OT. However, this limitation vanished at warmer than OT regimes. Physiological mechanisms to overcome the photosynthetic limitation imposed by $\mathrm{P}$ deficiency at warmer $\mathrm{T}$ regimes included the sustained photobiochemical traits such as carboxylation capacity (i.e., $\mathrm{V}_{\mathrm{Cmax}}$ ) and photosystem functions (i.e., SPAD value and $\left.\Phi_{\mathrm{PSI}}\right)$ and $\mathrm{CO}_{2}$ diffusion process by reducing stomatal limitation $\left(\mathrm{L}_{\mathrm{S}}\right)$ while mesophyll limitation $\left(\mathrm{L}_{\mathrm{M}}\right)$ remained unaffected. In the same situations, a marked increase in nutrient ( $\mathrm{P}$ and $\mathrm{N}$ ) utilization efficiency was also found indicating optimization of metabolic processes through better allocation of the available pool of nutrients. Results highlighted that warmer than OT used in this study compensated a decrease in the rate of leaf photosynthesis due to P deficiency despite the lower foliar P concentration of soybean. Thus, in view of predicted changes in climate and fertility stress, the plant photosynthesis-related processes are likely to benefit from a greater than optimum temperature in moderately P-limited environment when grown under well-watered conditions.

\section{References}

Baker J.T., Kim S.H., Gitz D.C. et al.: A method for estimating carbon dioxide leakage rates in controlled-environment chambers using nitrous oxide. - Environ. Exp. Bot. 51: 103110, 2004.

Bernacchi C.J., Portis A.R., Nakano H. et al.: Temperature response of mesophyll conductance. implications for the determination of rubisco enzyme kinetics and for limitations to photosynthesis in vivo - Plant Physiol. 130: 1992-1998, 2002.

Bown H.E., Watt M.S., Mason E.G. et al.: The influence of nitrogen and phosphorus supply and genotype on mesophyll conductance limitations to photosynthesis in Pinus radiata. Tree Physiol. 29: 1143-1151, 2009.

Bunce J.A.: Use of the response of photosynthesis to oxygen to estimate mesophyll conductance to carbon dioxide in waterstressed soybean leaves. - Plant Cell Environ. 32: 875-881, 2009.

Campbell W.J., Allen J.L.H., Bowes G.: Response of soybean canopy photosynthesis to $\mathrm{CO}_{2}$ concentration, light, and temperature. - J. Exp. Bot. 41: 427-433, 1990.

Cassman K.G., Whitney A.S., Fox R.L.: Phosphorus requirements of soybean and cowpea as affected by mode of $\mathrm{N}$ nutrition. Agron. J. 73: 17-22, 1981.

Cordell D., Drangert J.-O., White S.: The story of phosphorus: Global food security and food for thought. - Global Environ. Chang. 19: 292-305, 2009.

Cure J.D., Rufty T.W., Israel D.W.: Phosphorus stress effects on growth and seed yield responses of nonnodulated soybean to elevated carbon dioxide. - Agron. J. 80: 897-902, 1988.

Edwards G.E., Baker N.R.: Can $\mathrm{CO}_{2}$ assimilation in maize leaves be predicted accurately from chlorophyll fluorescence analysis? - Photosynth. Res. 37: 89-102, 1993.

Fleisher D.H., Timlin D.J., Yang Y. et al.: Uniformity of soilplant-atmosphere-research chambers. - T. ASABE 52: 1721$1731,2009$. 
Fleisher D.H., Wang Q., Timlin D.J. et al.: Response of potato gas exchange and productivity to phosphorus deficiency and carbon dioxide enrichment. - Crop Sci. 52: 1803-1815, 2012.

Geiger D.R., Servaites J.C.: Diurnal regulation of photosynthetic carbon metabolism in $\mathrm{C}_{3}$ plants. - Annu. Rev. Plant Phys. 45: 235-256, 1994

Grassi G., Magnani F.: Stomatal, mesophyll conductance and biochemical limitations to photosynthesis as affected by drought and leaf ontogeny in ash and oak trees. - Plant Cell Environ. 28: 834-849, 2005.

Hartman, G.L., West, E.D., Herman, T.K.: Crops that feed the World 2. Soybean-worldwide production, use, and constraints caused by pathogens and pests. - Food Sec. 3: 5-17, 2011.

Hewitt E.J.: Sand and Water Culture Methods Used in the Study of Plant Nutrition. Tech. Comm. 22. Pp. 187-190. Commonwealth Bureau of Horticulture and Plantation Crops. Bucks, Commonwealth Agricultural Bureau Farnham Royal, Maidstone, Kent. Bucks 1952.

Hidaka A., Kitayama K.: Divergent patterns of photosynthetic phosphorus-use efficiency versus nitrogen-use efficiency of tree leaves along nutrient-availability gradients. - J. Ecol. 97: 984-991, 2009.

Hikosaka K., Ishikawa K., Borjigidai A. et al.: Temperature acclimation of photosynthesis: mechanisms involved in the changes in temperature dependence of photosynthetic rate. J. Exp. Bot. 57: 291-302, 2006.

Israel D.W., Rufty T.W.: Influence of phosphorus nutrition on phosphorus and nitrogen utilization efficiencies and associated physiological responses in soybean. - Crop Sci. 28: 954-960, 1988.

Jacob J., Lawlor D.W.: Extreme phosphate deficiency decreases the in vivo $\mathrm{CO}_{2} / \mathrm{O}_{2}$ specificity factor of ribulose 1,5-bisphosphate carboxylase-oxygenase in intact leaves of sunflower. - J. Exp. Bot. 44: 1635-1641, 1993.

Jin J., Wang G., Liu X. et al.: Interaction between phosphorus nutrition and drought on grain yield, and assimilation of phosphorus and nitrogen in two soybean cultivars differing in protein concentration in grains. - J. Plant Nutr. 29: 14331449, 2006.

Jones H.G.: Partitioning stomatal and non-stomatal limitations to photosynthesis. - Plant Cell Environ. 8: 95-104, 1985.

Kim S.-H., Gitz D.C., Sicher R.C. et al.: Temperature dependence of growth, development, and photosynthesis in maize under elevated $\mathrm{CO}_{2}$. - Environ. Exp. Bot. 61: 224-236, 2007.

Koerselman W., Meuleman A.F.M.: The vegetation N:P ratio: a new tool to detect the nature of nutrient limitation. - J. Appl. Ecol. 33: 1441-1450, 1996

Koti S., Reddy K.R., Kakani V.G. et al.: Effects of carbon dioxide, temperature and ultraviolet-B radiation and their interactions on soybean (Glycine $\max$ L.) growth and development. Environ. Exp. Bot. 60: 1-10, 2007.

Lobell D.B., Asner G.P.: Climate and management contributions to recent trends in U.S. agricultural yields. - Science 299: 1032, 2003.

Manoj K., Swarup A., Patra A.K. et al.: Effect of elevated $\mathrm{CO}_{2}$ and temperature on phosphorus efficiency of wheat grown in an inceptisol of subtropical India. - Plant Soil Environ. 58: 230-235, 2012

Marschner H.: Mineral Nutrition of Higher Plants. $2^{\text {nd }}$ ed. Pp. 265-276. Academic Press, Orland 1995.

Martineau J.R., Williams J.H., Specht J.E.: Temperature tolerance in soybean. II. Evaluation of segregating populations for membrane thermostability. - Crop Sci. 19: 79-81, 1979.

Maxwell K., Johnson G.N.: Chlorophyll fluorescence: A practical guide. - J. Exp. Bot. 51: 659-668, 2000.
Mitchell R.A.C., Mitchell V.J., Driscoll S.P. et al.: Effects of increased $\mathrm{CO}_{2}$ concentration and temperature on growth and yield of winter wheat at two levels of nitrogen application. Plant Cell Environ. 16: 521-529, 1993.

Mittler R.: Abiotic stress, the field environment and stress combination. - Trends Plant Sci. 11: 15-19, 2006.

Murakami Y., Tsuyama M., Kobayashi Y. et al.: Trienoic fatty acids and plant tolerance of high temperature. - Science 287: 476-479, 2000.

Oberhuber W., Edwards G.E.: Temperature dependence of the linkage of quantum yield of Photosystem II to $\mathrm{CO}_{2}$ fixation in $\mathrm{C}_{4}$ and $\mathrm{C}_{3}$ plants. - Plant Physiol. 101: 507-512, 1993.

Ort D.R., Baker N.R.: A photoprotective role for $\mathrm{O}_{2}$ as an alternative electron sink in photosynthesis? - Curr. Opin. Plant Biol. 5: 193-198, 2002.

Plank C.O.: Plant Analysis Reference Procedures for the Southern Region of the United States: Southern Cooperative Series Bulletin \#368. Pp. 68. University of GA., Athens, GA 1992.

Rogers G.S., Payne L., Milham P., Conroy J.: Nitrogen and phosphorus requirements of cotton and wheat under changing atmospheric $\mathrm{CO}_{2}$ concentrations. - Plant Soil 155: 231-234, 1993.

Römheld V., Kirkby E.: Research on potassium in agriculture: needs and prospects. - Plant Soil 335: 155-180, 2010.

RosenthalD.M., Ruiz-Vera U.M., Siebers M.H. etal: :Biochemical acclimation, stomatal limitation and precipitation patterns underlie decreases in photosynthetic stimulation of soybean (Glycine max) at elevated $\left[\mathrm{CO}_{2}\right]$ and temperatures under fully open air field conditions. - Plant Sci. 226: 136-146, 2014.

Ruiz-Vera U.M., Siebers M., Gray S.B. et al.: Global warming can negate the expected $\mathrm{CO}_{2}$ stimulation in photosynthesis and productivity for soybean grown in the midwestern united states. - Plant Physiol. 162: 410-423, 2013.

Sanglard L.M.V.P., Martins S.C.V., Detmann K.C. et al.: Silicon nutrition alleviates the negative impacts of arsenic on the photosynthetic apparatus of rice leaves: an analysis of the key limitations of photosynthesis. - Physiol. Plantarum 152: 355366,2014

Sharkey T.D., Bernacchi C.J., Farquhar G.D., Singsaas E.L.: Fitting photosynthetic carbon dioxide response curves for $\mathrm{C}_{3}$ leaves. - Plant Cell Environ. 30: 1035-1040, 2007.

Sinclair T.R.: Mineral nutrition and plant growth response to climate change. - J. Exp. Bot. 43: 1141-1146, 1992.

Singh S.K., Reddy V.R., Fleisher H.D., Timlin J.D.: Growth, nutrient dynamics, and efficiency responses to carbon dioxide and phosphorus nutrition in soybean. - J. Plant Int. 9: 838849, 2014.

Singh S.K., Reddy V.R.: Response of carbon assimilation and chlorophyll fluorescence to soybean leaf phosphorus across $\mathrm{CO}_{2}$ : Alternative electron sink, nutrient efficiency and critical concentration. - J. Photochem. Photobio. B 151: 276-284, 2015.

Singh S.K., Reddy V.R.: Methods of mesophyll conductance estimation: its impact on key biochemical parameters and photosynthetic limitations in phosphorus stressed soybean across $\mathrm{CO}_{2}$. - Physiol. Plantarum 157: 234-254, 2016.

Singh S.K., Reddy V.R.: Co-regulation of photosynthetic processes under potassium deficiency across $\mathrm{CO}_{2}$ levels in soybean: mechanisms of limitations and adaptations. Photosynth. Res. 137: 183-200, 2018.

Sionit N., Strain B.R., Flint E.P.: Interaction of temperature and $\mathrm{CO}_{2}$ enrichment on soybean: Photosynthesis and seed yield. Can. J. Plant Sci. 67: 629-636, 1987.

Staswick P.E., Huang J.-F., Rhee Y.: Nitrogen and methyl jasmonate induction of soybean vegetative storage protein genes. - Plant Physiol. 96: 130-136, 1991. 
Stocker T.F., Qin D., Plattner G-K. et al. (ed.): IPCC. Climate Change 2013: The Physical Science Basis. Contribution of Working Group I to the Fifth Assessment Report of the Intergovernmental Panel on Climate Change. Pp. 1535. Cambridge University Press, Cambridge and New York 2013.

Suriyagoda L.D.B., Ryan M.H., Renton M., Lambers H.: Adaptive shoot and root responses collectively enhance growth at optimum temperature and limited phosphorus supply of three herbaceous legume species. - Ann. Bot.London 110: 959-968, 2012.

Taiz L., Zeiger E., Møller I.M., Murphy A.: Plant Physiology and Development. Pp. 761. Sinauer Associates, Inc., Sunderland 2014.

Taub D.: Effects of rising atmospheric concentrations of carbon dioxide on plants. - Nat. Educ. Knowledge 3: 21, 2010.

Timlin D.J., Naidu T.C.M., Fleisher D.H., Reddy V.R.: Quantitative effects of phosphorus on maize canopy photosynthesis and biomass. - Crop Sci. 57: 3156-3169, 2017.

van Kooten O., Snel F.H.J.: The use of chlorophyll fluorescence nomenclature in plant stress physiology. - Photosynth. Res. 25: 147-150, 1990.
Walker W.M., Raines G.A., Peck T.R.: Effect of soybean cultivar, phosphorus and potassium upon yield and chemical composition. - J. Plant Nutr. 8: 73-87, 1985.

Warren C.R.: Does growth temperature affect the temperature responses of photosynthesis and internal conductance to $\mathrm{CO}_{2}$ ? A test with Eucalyptus regnans. - Tree Physiol. 28: 11-19, 2008.

Warren C.R.: How does P affect photosynthesis and metabolite profiles of Eucalyptus globulus? - Tree Physiol. 31: 727-739, 2011.

Xu G., Singh S.K., Reddy V.R. et al.: Soybean grown under elevated $\mathrm{CO}_{2}$ benefits more under low temperature than high temperature stress: Varying response of photosynthetic limitations, leaf metabolites, growth, and seed yield. - J. Plant Physiol. 205: 20-32, 2016.

Zheng G., Tian B., Zhang F. et al.: Plant adaptation to frequent alterations between high and low temperatures: remodeling of membrane lipids and maintenance of unsaturation levels. Plant Cell Environ. 34: 1431-1442, 2011.

(C) The authors. This is an open access article distributed under the terms of the Creative Commons BY-NC-ND Licence. 